\title{
Empirical Research Regarding the Migration of Highly Qualified Human Resources From Romania - Example from the Medical Field -
}

\author{
${ }^{1}$ Dan Popescu, ${ }^{2}$ Cătălina Georgiana Picu, ${ }^{3}$ Andrei-Constantin Popescu
}

\begin{abstract}
:
As a direct consequence of globalisation and internationalization on the one hand and of the liberalization of markets and technological advances on the other hand, the international migration of highly qualified human resources is experiencing an ever more alarming growth because of its size and, in particular, of its implications. Adapting to a more and more unpredictable socio-economic environment, as a result of a fierce struggle for survival and for sustainable development requires that each and every company globalises its strategies, structures, resources and markets. The progress achieved in terms of technique and technology, along with the liberalization of the commodities, services and capital markets have generated new opportunities, as well as new threats for the organizations all over the world. Our research aims at highlighting to what extent the international migration of highly qualified human resources from Romania - in particular in the healthcare sector - can have a severe impact on the prospects of Romania's sustainable and durable economic development. At the end, we formulate a number of proposals, which, in our opinion, could decrease the exodus of highly qualified human resources, and especially that of medical doctors, to third markets.
\end{abstract}

Keywords: qualified human resources, brain drain, migration, medical doctors

JEL Codes: I19, M48, M51, M54

\section{Introduction}

The digital era has generated an unpredictable social and economic environment (State et Toancă, 2016:7) where, in order to survive, more and more companies have globalised their strategy, structures, resources and markets, in an attempt to obtain higher economic efficiency (Hitt, Ireland and Hoskisson, 2016:19). On the other hand, the enhanced competition for attracting human capital, especially highly qualified one, has prompted numerous governments to adopt special measures in order to attract and retain specialists in fields such as: information and communication technology (IT\&C), nanotechnology, biotechnology, healthcare, etc. These measures have stimulated the emigration of highly qualified specialists, especially from less developed to more developed economies. Over the last decade, Romanian and other Eastern European graduates have displayed a significant inclination towards emigration (Zahra, 2017:24). This is not a surprising phenomenon if we take into account the limited (although increasing) attractive career opportunities in this region. Consequently, numerous scientists from Eastern Europe were attracted by the United States, Canada and other Western countries (Dubinski, 
2012), which favoured and facilitated the access of certain categories of qualified foreigners. In Romania's case, between the years 2007 (the year of accession to the European Union - EU) and 2017, over one million residents emigrated from Romania (Eurostat, 2017, December 21). Between 2016, January 1, and 2017, January 1, the resident population numbers went down by 122 thousand people, reaching 19,638 thousand inhabitants. After the negative natural growth (-68,061 people in the above-mentioned interval), the second cause of the decrease in the population residing in Romania is represented by the exodus of the human resources to the developed western countries (Romanian National Statistical Institute, 2017, October, 22). The demographic aging phenomenon continues to amplify and the gap between the 65 and over year-old population and the young population (0-14) has reached 440,000 people $(3,494,000$ compared to 3,054,000 people), higher by 371,000 people compared to 2016, January 1. Practically, during the analysed interval, the aging index went up from 112.1 (2016, January 1) to 114.4 elderly people at 100 young people (2017, January 1). The balance of temporary, long term international migration was negative (-76,208 people). In total, men prevailed both as far as emigration (55.4\%) and immigration (53.6\%) are concerned (Romanian National Statistical Institute, 2017, October 22). As for the "export" of highly skilled workforce, according to the data centralized by the European Forum Alpbach (EFA), Romania ranks third in the top of European countries which exported for free highly qualified specialists trained in-country, the first two places being held by Poland and Germany (European Forum Alpbach, 2017, November 19). If in other countries the "brain drain" was strongly counterbalanced by immigration, Romania is deeply affected by a net loss of highly qualified human resources (Voicu, 2014, August 28). According to the statistics centralized by EFA, between 2003 and 2014, 26,296 highly qualified specialists left Romania in order to work in western states. During the same period, 10,179 people left Hungary, but many specialists came instead, especially from Romania or Slovakia. The lowest specialists' migration rate took place in France which lost only 9585 people in a decade.

The migration phenomenon was beneficial to the UK, Germany, Belgium, Austria and surprisingly Cyprus (de Lima et all, 2016:19-20).

It is a sure fact that governments encourage or ignore the free specialists export. Within this context, more than 15 years ago the World Bank warned developing countries on the loss of highly trained specialists they would incur soon enough (Sarwar Lateef, 2016, January 21). Practically, the governments of poorer states invest in university education, which is free in many cases, while rich states take advantage of it. Besides the direct losses, the brain drain reduces the capacity of poor countries to bridge the gap which separates them from the developed ones. As a possible solution, the World Bank specialists proposed to the states affected by brain drain to impose a series of sanctions in the form of financial compensations to be paid by the ones who leave the country after graduation (Shah, 2013, March 24). Alternatively, another possible variant would be that they replace the free higher education with a system of scholarships offered by the government to the ones who sign 5-10 years contracts with companies or institutions in their country of origin. No Romanian government has wanted to tackle this issue and has done something, except for some very pompous declarations of intention. 
On the contrary, the free export of specialists was seen as a solution to equilibrate the balance of payments with the money they send to their relatives who remained in the country or as a possible solution for the unemployment, in the absence of programmes to stimulate the creation of workplaces for the highly skilled.

In Table 1 contents we presents a synoptic situation of the emigration/immigration phenomenon in Europe (Eurostat - Statistical Books - Key Figures in Europe - 2017, September 30):

Table 1: Immigrants situation at the end of the year 2015

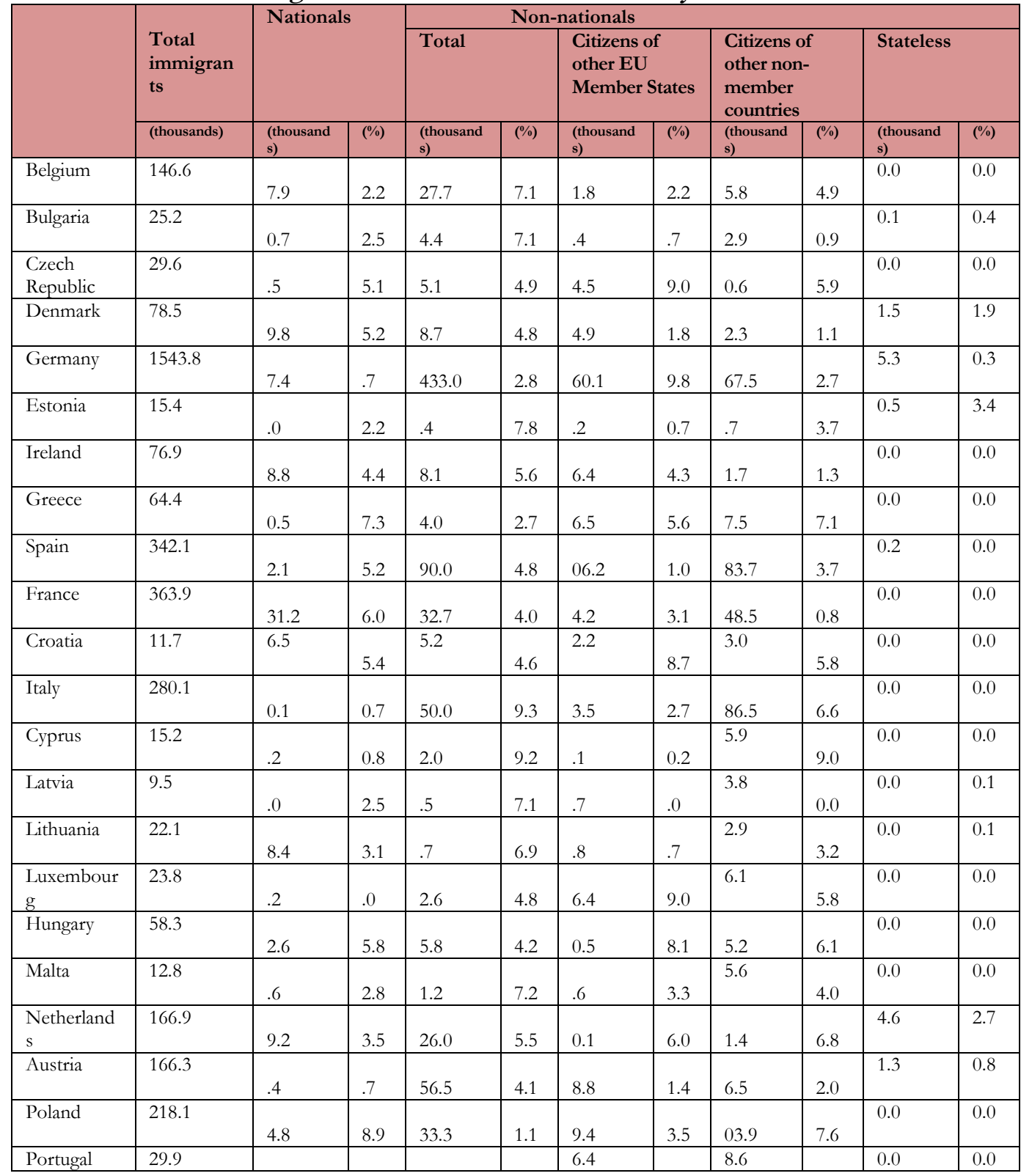




\begin{tabular}{|c|c|c|c|c|c|c|c|c|c|c|c|}
\hline & & 4.9 & 0.0 & 4.9 & 0.0 & & 1.2 & & 8.7 & & \\
\hline Romania & 132.8 & 15.5 & 7.0 & 7.2 & 3.0 & 8.2 & .2 & 9.0 & .8 & 0.0 & 0.0 \\
\hline Slovenia & 15.4 & 2.8 & 7.9 & 2.7 & 2.1 & 2.8 & 7.9 & 9.9 & 4.2 & 0.0 & 0.0 \\
\hline Slovakia & 7.0 & 3.2 & 6.1 & 3.8 & 3.9 & 3.1 & 4.4 & 0.7 & .5 & 0.0 & 0.0 \\
\hline Finland & 28.7 & 7.3 & 5.5 & 0.8 & 2.3 & 7.6 & 6.5 & 3.1 & 5.6 & 0.1 & 0.2 \\
\hline Sweden & 134.2 & 0.4 & 5.2 & 13.4 & 4.4 & 9.8 & 2.2 & 8.2 & 8.2 & 5.4 & 4.1 \\
\hline $\begin{array}{l}\text { United } \\
\text { Kingdom }\end{array}$ & 631.5 & 3.6 & 3.2 & 47.8 & 6.8 & 69.2 & 2.6 & 78.6 & 4.1 & 0.0 & 0.0 \\
\hline Iceland & 5.6 & 1.8 & 1.6 & 3.9 & 8.8 & 3.1 & 5.0 & 0.7 & 3.2 & 0.0 & 0.3 \\
\hline $\begin{array}{l}\text { Liechtenstei } \\
\mathrm{n}\end{array}$ & 0.7 & 0.2 & 4.8 & 0.5 & 5.2 & 0.3 & 1.2 & 0.2 & 3.9 & 0.0 & 0.0 \\
\hline Norway & 60.8 & 6.9 & 1.3 & 3.9 & 8.7 & 7.1 & 4.6 & 6.0 & 2.8 & 0.8 & 1.4 \\
\hline Switzerland & 153.6 & 6.0 & 6.9 & 27.6 & 3.1 & 0.2 & 8.7 & 7.4 & 4.3 & 0.0 & 0.0 \\
\hline
\end{tabular}

Note: The individual values do not add up to the total due to rounding and the exclusion of the unknown citizenship group from the table

The data in Table 1 indicates that, at the level of 2015: (a) a total of 4.7 million people immigrated to one of the $28 \mathrm{EU}$ Member States, while at least 2.8 million emigrants were reported to have left an EU Member State. These total figures do not represent the migration flows to/from the $\mathrm{EU}$ as a whole, since they also include flows between different EU Member States; (b) among these 4.7 million immigrants, there were 2.4 million citizens of non-member countries, 1.4 million people with citizenship of a different EU Member State from the one to which they emigrated, around 860,000 people who migrated to an EU Member State of which they had the citizenship (example: returning nationals or nationals born abroad), and some 19,000 stateless people; (c) the immigrants' favourite destinations were, in order: Germany, with 1543,8 million immigrants, of which 460.1 thousand (29.8\%) from EU Member States and 967.5 thousand (62.7\%) from other countries; the United Kingdom, with 631.5 thousand immigrants, of which 269.2 thousand (42.6\%) from EU Member States and 278.6 thousand (44.1\%) from other countries; France, with 363.9 thousand immigrants, of which 84.2 thousand (23.1\% of the total) from EU Member States and 148.5 thousand (40.8\% of the total) from other countries.

\section{Goals, Methodology, Results}

The main objective of this research study was to establish the situation of the migration phenomenon of highly qualified buman resources from Romania, in particular in the healthcare field, and the measures which can diminish or even eliminate this scourge.

The structured questionnaire and the interview were used as research techniques.

The fact that Romania boasts one the fastest growing economies in the EU that means 5\% according to Eurostat at the end of 2017 (Bayer, 2018, January 18) cannot counterbalance the problematic combination between the phenomena of an aging and decreasing population and the departure abroad of young and skilled workers, which put enormous 
pressure on the health and pensions systems. It is obvious that Romania needs an adequate strategy in order to persuade the highly qualified young people to return home (McGrath, 2017, January 30). The same author noted that as the number of those looking for a better life in the West, especially in Germany, Italy, Spain and the UK increased, Romania began to suffer from the brain drain phenomenon. The effect of the departure of Romanians with higher education and top professional skills is felt intensively. The most relevant example is not that of the IT\&C specialists, as one might believe, but that of the human resources in healthcare, especially that of medical doctors. Lately, thousands of employees have emigrated to more developed EU countries, where they benefit from higher salaries and better working conditions. The fact that abroad they can earn even 10 times more has led to a severe crisis of the staff in Romanian hospitals. Since 2007, more than 43 thousand employees in the health sector for the training of whom the Romanian state had spent more than 3.5 billion euro have left. (Voiculescu, 2017, October 22). Regarding the measures taken by the Romanian government to encourage the expats to return, Forbes refers to the programme by which each person who repatriates and intends to start a business in Romania receives grants 50 thousand euro, plus consultancy (Vrînceanu, 2017, August 30). In spite of this, the Romanians hesitate to return, also because "Romania is one of the most corrupt countries in the EU and despite a recent offensive against high level corruption, the people continue to display a deep lack of trust in the government" (Transparency International, 2018, February 21).

Our research also took into account the increasing interest in higher medical education, a fact also reflected in the statistical data in Table 2 (Eurostat - Statistical Books Key Figures in Europe - 2017, September 30):

Table 2: The situation of medical graduates in European countries

\begin{tabular}{|c|c|c|c|c|c|c|c|c|c|c|}
\hline & 2006 & 007 & 008 & 009 & 010 & 011 & 012 & 013 & 014 & 015 \\
\hline Germany & 8974 & 896 & 870 & 724 & 574 & 857 & 0069 & 894 & 572 & \\
\hline $\begin{array}{l}\text { United } \\
\text { Kingdom }\end{array}$ & 4641 & 805 & 176 & 576 & 208 & 873 & 040 & 102 & 233 & 183 \\
\hline Italy & 7282 & 615 & 415 & 143 & 816 & 796 & 682 & 732 & 699 & \\
\hline Turkey & 4380 & 487 & 494 & 532 & 899 & 872 & 753 & 087 & 138 & \\
\hline Spain & 4009 & 211 & 064 & 951 & 841 & 922 & 882 & 874 & 017 & \\
\hline Poland & 2509 & 605 & 349 & 308 & 550 & 727 & 788 & 081 & 349 & \\
\hline ROMANIA & 3268 & 372 & 195 & 920 & 745 & 542 & 774 & 900 & 031 & \\
\hline Netherlands & 1654 & 705 & 756 & 842 & 019 & 022 & 075 & 276 & 429 & \\
\hline $\begin{array}{l}\text { Czech } \\
\text { Republic }\end{array}$ & 1007 & 019 & 069 & 041 & 108 & 163 & 319 & 458 & 460 & \\
\hline Portugal & 603 & 94 & 36 & 12 & 029 & 101 & 126 & 262 & 287 & \\
\hline Hungary & 975 & 124 & 151 & 069 & 005 & 60 & 23 & 040 & 148 & \\
\hline Belgium & 1193 & 35 & 63 & 81 & 32 & 58 & 51 & 80 & 125 & \\
\hline Denmark & 711 & & & & & & & & & \\
\hline
\end{tabular}




\begin{tabular}{|c|c|c|c|c|c|c|c|c|c|c|}
\hline & & 73 & 18 & 58 & 75 & 08 & 41 & 07 & 37 & \\
\hline Switzerland & 625 & 75 & 22 & 94 & 12 & 67 & 29 & 13 & 44 & \\
\hline Ireland & 608 & 38 & 94 & 41 & 26 & 73 & 22 & 85 & 38 & \\
\hline Finland & 448 & 45 & 37 & 95 & 67 & 46 & 00 & 03 & 21 & 90 \\
\hline Bulgaria & 605 & 42 & 69 & 26 & 55 & 80 & 03 & 97 & 02 & \\
\hline Norway & 462 & 65 & 67 & 61 & 97 & 96 & 16 & 51 & 68 & \\
\hline Lithuania & 264 & 45 & 16 & 59 & 64 & 22 & 95 & 91 & 07 & \\
\hline Latvia & 104 & 5 & 4 & 24 & 11 & 40 & 61 & 79 & 32 & 34 \\
\hline Slovenia & 163 & 52 & 62 & 28 & 29 & 74 & 62 & 29 & 06 & \\
\hline Estonia & 103 & 7 & 06 & 28 & 06 & 12 & 20 & 49 & 25 & \\
\hline Malta & 37 & 8 & 8 & 0 & 0 & 0 & 1 & 9 & 1 & 7 \\
\hline Iceland & 30 & 5 & 4 & 0 & 6 & 9 & 7 & 4 & 4 & \\
\hline Liechtenstein & 0 & & & & & & & & & \\
\hline Greece & - & & 472 & 635 & 599 & & & & & \\
\hline France & 3828 & 562 & 441 & 354 & 843 & & & & & \\
\hline Croatia & 410 & 83 & 28 & 51 & 67 & 72 & & & & \\
\hline Luxembourg & - & & & & & & & & & \\
\hline Austria & 1599 & 732 & 693 & 604 & 976 & 968 & 906 & 673 & & \\
\hline Slovakia & 573 & 70 & 57 & 09 & 35 & 87 & 60 & & & \\
\hline Sweden & 838 & 98 & 04 & 10 & 32 & 46 & 93 & 02 & & \\
\hline Macedonia & 156 & 32 & 65 & 86 & 72 & 55 & 04 & 02 & & \\
\hline TOTAL & - & & 2575 & 2362 & 6288 & & & & & \\
\hline
\end{tabular}

Our scientific research consisted in drawing up and distributing a questionnaire containing 20 questions, which was answered by 496 medical doctors from Romania and the diaspora.

The answers to this questionnaire have revealed the following main conclusions:

1. Most respondents are male (286 people, i.e. $57.66 \%$ of the total), the age of most of the respondents falling into the "30 - 40 years old" interval (413 people, i.e. $83.27 \%$ of the total);

2. Most respondents are medical staff with high education (medical doctors: 315 representing $63.51 \%$ of the total), the other 181 (26.49\% of the total) being medical assistants. The majority of the respondents (392 people, i.e. $79.03 \%$ of the total) work in Romania. Only 273 of the respondents are married (55.04\% of the total);

3. For the question ("Why would you leave/have you left Romania?"), most of them (389, meaning $78.43 \%$ of the respondents) chose as an answer "Because of the salary". 57 people (11.49\%) chose the option "Because of the working conditions", which, in our opinion, is surprisingly serious. Another 50 people $(10.08 \%$ of the total) chose the option "Other causes" 
(mentioned as being, mostly: lack of viable professional development, the precarious and unpredictable environment, a perceived lack of respect of society towards medical doctors, etc.);

4. Among the professional priorities for the next 20-30 years, obviously taking into account the average age (31 - 40 years) of most of the respondents (413 people), are the following: 293 people (59.07\% of the total) chose the "personal development" variant; 148 people (29.84\% of the total) chose the answer "better working conditions"; 55 of the participants in the study $(11.09 \%$ of the total) chose the variant "fulfilment in a professionally superior environment than the one in Romania";

5. There were interesting reactions to the questions referring to the salaries and income in Romania in general. Thus, none of the 392 respondents declared himself/ herself satisfied with the salary received in Romania but when it came to the question (with anonymous answers obviously) "Do you accept to receive undeserved benefits?", there was total honesty on the part of the respondents: 368 (93.88\% of the total number who carry out their activity in Romania) gave an affirmative answer. There is no wonder that although many of those who work in the healthcare system complain about the low salaries, there are medical doctors and medical assistants (especially specializing in Surgery and Neurology) whose average monthly income (in lei equivalent) is of approximately 10000 and around 2800 euro respectively, which is normally much above the salaries in developed European countries;

6. Another interesting aspect is the fact that none of the 104 respondents who work outside the country would come back to Romania, although many statistics maintain that a raise in salaries in Romania would generate the repatriation of a significant number of medical staff. Within this context there are even governmental promises offering each repatriated person a 45 thousand euro allowance (the promises increased from 25 thousand euro in 2009). In our opinion, such aspects are mainly related to electoral publicity and political marketing;

7. According to the respondents, among the priorities which should be solved at national level are: (a) the money issue; (b) creating some specialized excellence centers (hospitals); (c) adopting long term strategies, which should offer more predictability and implicitly, more stability to the medical system; (d) eliminating the interference of the political in the economic life in general and in the healthcare system in particular. In this sense, although in 27 years there were no less than 30 ministers of health, the reform of the health system is a theoretical wish. If a real reform took place in the healthcare system, many of those who are at the top of the system and its subunits would lose their privileges, which is unacceptable for many;

8. Introduction of financial order and discipline. The majority of our medical doctors professionally they are very good. However, hospital management is extremely poor and in most cases the decisions are of a strictly subjective nature.

The results of our study have also revealed an aspect with a deep dramatic significance for Romania: statistically, nine Romanians leave their country every hour (Bulai, 2017, July 25). This means that annually, Romania is deserted by almost 79,000 inhabitants, the equivalent of the population of an average-sized town. Those who leave Romania do it in the hope of managing to save money and then come back. Besides the demographic aspects, maybe the most negative reality is the fact that Romania is also losing its investment in the training of human resources, especially that those who are building their future in other countries belong to the category of university graduates. Furthermore, Romania loses annually over 1 billion euro because of the lack of this workforce. The main reason why young people below 25 are leaving the country is that 
they are graduates of faculties/ specializations with profiles that do not ensure them work places or for which there are very few jobs available on the labour market. In the medical doctors' case, they emigrate in bigger and bigger numbers, while the interest in medical schools has soared. This is not because they want to practice medicine in Romania, where the salaries and social recognition are considered to be deeply demotivating. Of the 9 Romanians who decide to leave their country every hour, two thirds, meaning 6 people, are medical doctors (Bulai, 2017, July 25). From this we can conclude that we invest in training doctors for richer countries, which is a priori a nonsense. Therefore, the population of Romania is decreasing at a rapid pace. Only in January 2017, our country lost 13,700 inhabitants (Tudorel, 2017, April 20). According to official statistics, at the beginning of 2016, Romania was on the seventh place in the EU population wise: our country's 19.760 million inhabitants accounted for 3.9 per cent of the EU population. Ahead of us were Germany with 16,1\% of the EU population; France: 13.1\%; UK: 12.8\%; Italy: 11.9\%; Spain: with 9.1\%; Poland: 7.4\% (Eurostat, 2017. December 21). Unfortunately, it is almost sure that Romania will lose this place; the specialists estimate that during the next 30 years, our country's population will experience a dramatic fall and will not come above 14-15 million inhabitants. More than this, the specialists from the Romanian Statistical National Institute (RSNI) are warning that, in case the politicians do not become actively involved in developing coherent demographic policies, the Romanian people is running the risk of disappearing.

An United Nations Report reveals that in the diaspora there are 3.4 million Romanians, representing 17\% of the country's population (Alexe, February, 2018 26). This is one of the highest percentages for a country that was not affected by armed conflicts, ranking $18^{\text {th }}$ in a top including countries such as Syria, Moldavia, Puerto Rico, etc. At the same time, RSNI estimates that Romania's population has gone down by 2 million people during the last 10 years as a consequence of emigration (Tudorel, 2017, April 20).

\section{Conclusions}

The main problems facing Romania in terms of brain drain and, generally speaking, its economy, are the following:

1. a negative rate of natural increase (in 2016 the decrease in population was of more than 75 thousand people); this percentage is the tragic consequence of the precarious situation of our healthcare system. To make things even clearer, the Romanian NIS announced that Romania's population went down daily by 247 people in 2016 (Alexe, 2018, February 26);

2. Romania is on the second place in the world when it comes to the human resources migration. According to the UN statistics, the number of Romanians abroad increased annually by over 7\% between 2000 and 2015 (Alexe, 2018, February 26). The only country which had a higher migration rate was Syria, for an obvious reason - the civil war that is tormenting that country. The Romanians instead are economic migrants and they have come to have the biggest diaspora in the EU, after the UK, Germany and Poland. At the end of 2016, 3.4 million Romanian citizens lived abroad, much over the official estimates of the Romanian authorities. Having started in Romania immediately after the revolution in December 1989, the migration phenomenon increased every year, especially after the 
accession to the EU offered Romanians unlimited access to work places in Western countries. Between 2000 and 2015, the number of Romanians abroad went up on average by $7.3 \%$ per year. Romania is the country with the highest increase in the migration rate due to economic reasons. In order to have a clearer image, we mention that the Romanian diaspora represents $17 \%$ of the total population which remained in the country, while in Poland this accounts for only 11\%. We have lost 3.4 million employees because of migration. An estimate of the National Bank of Romania (NBR) indicated that in 2014 the GDP would have been higher by 50 billion euro if the Romanians abroad had worked in the country, in the same sectors in which they are employed abroad. Between 2000 and 2016, the Romanians in the diaspora sent 60 billion euro home, but after 2008 the amounts started to gradually go down. The reasons are related, on the one hand, to the crisis which hit the EU after that year and on the other hand to the fact that the Romanians abroad started to bring their families in the countries they had moved to and had no more reasons to send money home (Alexe, 2018, February 26);

3. the phenomenon of the medical doctors' migration has reached most alarming levels, with Romania losing more than 43 thousand of them in only 10 years, while the investment made to train them amounted to more than 3.5 billion euro. Practically, this amount is not an investment, but an irrecoverable loss. On the other hand, paradoxically, the Romanian government has recently signed a contract with the Organization for Economic Cooperation and Development (OECD) worth 75 thousand euro, the aim of which is to carry out a study regarding the Romanian communities (including the most important reasons of the emigration and the factors which could trigger the return to their country of origin);

4. the phenomenon of the medical doctors' migration is doubled by that of the considerable diminishing of the number of highly qualified human resources in healthcare. The low income level, the very poor working conditions, the acute lack of high-performance equipment, the limited professional development opportunities, plus the system's "negative rate of increase": every year, 3,000 medical doctors join the Romanian healthcare system, but 3,500 leave it as a consequence of retirement, death and especially migration (Alexe, 2018, February 26). According to statistics, in 2013 the number of medical human resources who emigrated from Romania equalled the one of medical school graduates: 3,000. Also in 2013, Romania had the lowest number of medical doctors per 100 thousand inhabitants: 130.2, compared to 269.3 per 100 thousand in Denmark, 190.4 per 100 thousand in Germany, 338 per 100 thousand inhabitants in Lithuania, etc. On the other hand, the medical doctors' deficit in Romania at the end of 2016 was of $26.7 \%$, the main causes being not only migration, but also the hospital management incompetence. Incredibly, on top of this there were the lack of concern and/or even the indolence of decision makers.

\section{References}

Alexe, A. (2018, February 26). "3,4 million Romanians left the country in the last 10 years; the second highest emigration growth rate after Syria". Retrieved from http://www.business-review.eu/ news/3-4-million-romanians-left-the-country-in-the-last-10-years-second-highest-emigration-rate after-syria-159038/

Bayer, L. (2018, January 18). "Europe's Eastern Tigers roar ahead. Governments aim to convert boom into political clout". Retrieved from https://www.politico.eu/article/central-and-eastern-eu-gdpgrowth-economies/ 
Bulai, E. (2017, July 25). "Every hour, Romania is left by 9 inhabitants". Retrieved from https:// www.digi24.ro/stiri/actualitate/social/noua-romani-pleaca-din-tara-in-fiecare-ora-766953/

"Demography and migration", Eurostat (2017, January 23). Retrieved from http://ec.europa.eu/ eurostat/data/database/

"Demography and migration", Eurostat (2017, October 22). Retrieved from http://ec.europa.eu/ eurostat/data/database/

"Demography and migration", Eurostat (2017, December 21). Retrieved from http://ec.europa.eu/ eurostat/data/database/

Dubinsky, V. (2012, October 22). "How Communism Took Over Eastern Europe After World War II". Retrieved from https://www.theatlantic.com/international/archive/2012/10/how-communism took-over-eastern-europe-after-world-war-ii/263938/

European Forum Alpbach (2017, November 19). Retrieved from https://www.alpbach.org/en/

"Eurostat Statistics Explained - Healthcare personnel statistics - physicians", Eurostat (2017, September 30). Retrieved from http://www.ec.europa.eu/eurostat/statistics-explained/index.php/ Healthcare personnel statistics-physicians/

Hitt, M., Ireland, D., Hoskisson, R. (2016). Strategic Management: Concepts: Competitiveness and Globaliration. 12th Edition. Boston, MA: Cengage Learning

Lima, de, P, Bernabè, S., Bubbico, R.L., Leonardo, S., Weiss, C. "Migration and the EU. Challenges, opportunities, the role of EIB - European Investment Bank". (2016, March 16). Retrieved from http:// www.eib.org/attachments/migration_and_the_eu_en.pdf/

McGrath, S. "Romania is losing its mind and tries to stop the brain drain". (2017, January 30). Retrieved from https://www.forbes.com/sites/stephenmcgrath/2017/01/30/losing-your-mind-romanias- attempts-tocounter-the-brain-drain/\#4bf439855c84/

Popescu, D., State, C. "The crowdsourcing: an alternative for the dynamic development of entrepreneurship". Amfiteatru Economic Journal, 2015, 17/(38):165-182

State, C., Toancă, L. "The Impact of the Digital Era on the Strategic Management of SMEs", Proceedings of The International Multidisciplinary Scientific Conference on Social Sciences and Arts - SGEM, 2014, 4:745-754, Albena, Bulgaria

Popescu, D., Patrasca, M., Chivu, I. Tendencies of International Career of Romanian Researchers: Brain Drain? Journal of Applied Quantitative Methods (JAQM), 2006, 1/(2):194-209

Sarwar Lateef, K. (2016, January 21). "Evolution of The World Bank's thinking on Governance". Retrieved from http//www.pubdocs.worldbank.org/en/433301485539630301/WDR17-BP-Evolution- ofWB-Thinking-on-Governance.pdf/

Shah, A. (2013, March 24). "Structural Adjustment - A Major Cause of Poverty". Retrieved from http://www.globalissues.org/article/3/structural-adjustment-a-major-cause-of-poverty/

Transparency International (2018, February 21). "Corruption Perceptions Index 2017". Retrieved from https://www.transparency.org/news/pressrelease/corruption_perceptions_index_2017/

Tudorel, A. (2017, April 20). "Only in January 2017 Romania lost 13700 inhabitants". Retrieved from

Voicu, I. (2014, August 28). "Brain-drain masiv din România. Plecarea specialiştilor devastează societatea"/"Brain-drain massive in Romania. The departure of the specialists devastates the society". Retrieved from https://www.dcnews.ro/brain-drain-masiv-din-romania_452191.html/

Voiculescu, V. (2016, December 5). "43,000 medici au plecat din Romania". Retrieved from http//: www.ziare.com/social/medici/43-000-de-medici-au-plecat-din-romania-dupa-ce-am-intrat-in-uedoar-pregatirea-lor-ne-a-costat-3-5-miliarde-o-pierdere-irecuperabila-1445605

Vrînceanu, C. (2016, August 30). "Overseas Romanians returning Home Might Qualify for 50,000 euro Grants to Start up Business". Retrieved from http://www.nineoclock.ro/overseas-romaniansreturning-home-might-qualify-for-50000-euro-grants-to-start-up-businesses/

Zahra, T. (2017). The Great Departure: Mass Migration from Eastern Europe and the Making of the Free World. 1st Edition. New York: W. W. Norton \& Company

Romanian National Statistical Institute. (2017, October 22). Retrieved from https://www.inse.ro/ 